\title{
NONOBSTRUCTIVE CORONARY ARTERY DISEASE - CLINICAL RELEVANCE, DIAGNOSIS, MANAGEMENT AND PROPOSAL OF NEW PATHOPHYSIOLOGICAL CLASSIFICATION
}

\author{
Zorin Makarovići ${ }^{1,2}$, Sandra Makarović ${ }^{1,2}$, Ines Bilić-Ćurčićc \\ Ivan Mihaljević ${ }^{1,4}$ and Dražen Mlinarević ${ }^{1,2}$ \\ ${ }^{1}$ Faculty of Medicine, Josip Juraj Strossmayer University of Osijek, Osijek, Croatia; \\ ${ }^{2}$ Department of Cardiology, Osijek University Hospital Centre, Osijek, Croatia; \\ ${ }^{3}$ Department of Pharmacology, Faculty of Medicine, Josip Juraj Strossmayer University of Osijek, Osijek, Croatia; \\ ${ }^{4}$ Department of Nuclear Medicine and Radiation Protection, Osijek University Hospital Centre, Osijek, Croatia
}

\begin{abstract}
SUMMARY - New data gathered from large clinical trials indicate that nonobstructive coronary artery disease (non-CAD) is a clinical entity that should not be ignored. It is estimated that $50 \%$ of female population undergoing coronarography are diagnosed with non-CAD. There is also an increase in the prevalence of non-CAD in both genders, which is probably due to gradual expanding of clinical indications for angiography in patients with angina. Furthermore, considering the increased mortality risk established recently, a prognosis of non-CAD is not benign as previously thought. However, the concept and definition of non-CAD remains elusive causing difficulties in diagnosis and treatment. One of the major shortcomings is the exclusion-based diagnosis of non-CAD. Furthermore, treatment of non-CAD still presents a great challenge and optimal therapy is yet to be determined. There are two major hypotheses explaining the pathophysiological mechanisms of non-CAD, i.e. ischemic hypothesis based on abnormal microvascular dysfunction and non-ischemic one based on altered pain perception. This review encompasses a broader spectrum of pathophysiological mechanisms of non-CAD, and proposes a new way of classification based on the major disorder involved: type I (ischemic mechanisms) and type II (non-ischemic mechanisms), depending on which mechanism predominates. Hopefully, this would provide new insights in the understanding of this disorder, thus leading to accurate and early diagnosis and successful treatment, especially considering the increased mortality risk in these patients.
\end{abstract}

Key words: Coronary artery disease; Classification; Diagnosis; Angiography

\section{Introduction}

The concept of coronary syndrome X (CSX) was introduced in clinical practice in 1973 by Kemp et al. to describe patients with angina during physical exercise and normal coronarography ${ }^{1-3}$. Over time, this term has encompassed a broader spectrum of patients

Correspondence to: Assist. Prof. Sandra Makarović, MD, PhD, Dubrovačka 18, HR-31000 Osijek, Croatia

E-mail: sandramakarovic@yahoo.com

Received October 10, 2017, accepted February 19, 2018 including those with angina regardless of the cause and absence of significant changes on coronary vessels $^{2}$. Patients with other cardiac pathology such as cardiomyopathies, left ventricular hypertrophy or significant valvular disease are usually, although not always, excluded from this definition ${ }^{4}$. Many authors recommend associating this syndrome with angina and microvascular dysfunction ${ }^{5}$. On the other hand, some authors suggest exclusion of certain diseases, such as hypertension or diabetes, which can lead to microvascular dysfunction ${ }^{6}$. 
Classic definition of CSX is: angina during physical exertion, significant changes of ST segment during exercise test, and angiographically smooth coronary arteries in the absence of other cardiac or systemic diseases (e.g., hypertension and diabetes), which can lead to vascular dysfunction ${ }^{6}$. This definition is presently inappropriate for research and clinical purpose, the main objection being the impossibility of including all patients with microvascular dysfunction ${ }^{5}$. Hence, new, more appropriate definitions have recently been introduced by scientific community.

Lanza has proposed that CSX consists of chest pain predominantly during physical exertion, established ischemia or diminished coronary reserve, using noninvasive provocation tests, normal (or almost normal) coronary arteries at angiography with stenosis less than $<20 \%$, and exclusion of other specific diseases such as Prinzmetal's angina, cardiomyopathies and valvular heart disease ${ }^{5}$. Accordingly, the CSX now includes not only conditions with diminished coronary reserve that can be established with modern diagnostic procedures of ergometry, stress induced myocardial scintigraphy, pharmacological stress tests or ECG Holter monitor test, but also other diseases such as hypertension or diabetes, which are common causes of microvascular dysfunction ${ }^{7}$.

Owing to the new understandings, Cannon and Epstein introduced a new concept of microvascular angina in $1985^{\circ}$. This concept defines CSX as chest pain with normal coronary angiography associated with enhanced sensitivity of microcirculation to vasoconstrictive influences or abnormal vasodilatory response due to endothelial dysfunction. The level of endothelin (vasoconstrictor) in plasma of these patients is significantly increased ${ }^{9}$. This was an attempt to unite pathophysiology of the clinical condition, accentuate significant role of endothelial dysfunction, and achieve a more homogeneous group of patients. However, this approach is not fully satisfying since it becomes more obvious that endothelial dysfunction is only part of the pathophysiological cascade.

In 2011, Kothawade et al. suggested a new term of microvascular coronary dysfunction $(\mathrm{MCD})^{10}$. The CSX is defined as diminished coronary reserve and/or coronary endothelial dysfunction, and is clinically presented with a triad of symptoms: persistent chest pain, nonobstructive coronary disease (coronary artery stenosis $<50 \%$ on coronarography), and ischemia estab- lished with noninvasive methods ${ }^{10}$. The gold standard for MCD diagnosis is invasive coronary reactivity testing $(\mathrm{CRT})^{10}$.

Regardless of definition and terminology, it is necessary to emphasize that obstructive coronary disease (CAD) indicates stenosis of coronary vessel $\geq 50 \%$ on coronarography, while nonobstructive coronary disease (non-CAD) indicates stenosis of coronary artery $<50 \%{ }^{11}$. That criterion is common to all definitions and understandings of this complex clinical syndrome.

However, there are still some differences in understanding non-CAD that cause discrepancies in results and observations. Therefore, new definitions should be considered to enable unique and accurate defining of this clinical entity with all its diversities.

\section{Nonobstructive Coronary Artery Disease - Pathophysiological Mechanisms}

There are two major hypotheses explaining the pathophysiological mechanisms of non-CAD, i.e. ischemic and non-ischemic hypotheses ${ }^{12}$. Ischemic theory is based on abnormal microvascular dysfunction, whereas non-ischemic theory is grounded on altered pain perception ${ }^{12-16}$.

\section{Ischemic hypothesis}

Since the time when CSX was recognized as a specific clinical entity, it was assumed that chest pain was caused by dysfunction of small coronary arteries $(<500$ $\mu \mathrm{m})$, not seen during coronarography, hence naming the whole syndrome microvascular angina ${ }^{8}$. Myocardial ischemia in these patients can be established by ST segment changes at rest or exertion and by perfusion redistribution on scintigraphy ${ }^{13}$. Moreover, there is some metabolic evidence for ischemia during exercise, e.g., increased lactate production, decreased oxygen saturation in coronary sinus, decreased $\mathrm{pH}$ and increased phosphate consumption on nuclear magnetic resonance (NMR), which can be confirmed in $20 \%$ of patients ${ }^{15}$.

However, not all studies managed to demonstrate the presence of ischemia since disturbance of regional contractility was not confirmed by echocardiography ${ }^{16}$. In 1991, Maseri et al. ${ }^{14}$ tried to explain this contradictory observation with the following hypothesis. Microvascular dysfunction encompasses small prearterio- 
lar vessels $(100-500 \mu \mathrm{m})$, while their inadequate vasodilative response during exercise or pharmacological stress tests leads to localized ischemia surrounded by areas with functioning arteriolar vessels. This induces compensatory response by increasing contractility, thus preventing diagnosis of regional or global contractility disturbance by echocardiography.

Coronary flow is regulated by endothelial dependent and non-endothelial dependent factors, which regulate macro- and microvascular blood vessel tone. Endothelial dependent factors regulate coronary reserve modulating vasomotor tone by releasing vasoactive factors. The most important vasodilator is nitric oxide (NO), a factor released by endothelial cells. Non-endothelial dependent factors encompass aortal pressure, myocardial contractility output, neurohumoral mechanisms and myocardial metabolism ${ }^{17}$. Endothelial dysfunction leads to vasodilatory imbalance between NO and vasoconstrictor endothelin-1 and reduced release of anti-inflammatory and antithrombotic factors ${ }^{17}$.

Since microvascular dysfunction cannot be established by classic coronary angiography (coronarography) and there are no other available methods at present for visualizing vasculature smaller than $500 \mu \mathrm{m}$, other diagnostic methods are needed to indirectly demonstrate microvascular dysfunction. These tests can be invasive (thermodilution and invasive evaluation of coronary flow) or noninvasive (myocardial scintigraphy-radionuclide perfusion, positron emission tomography (PET), NMR) ${ }^{17}$.

The gold standard in the diagnosis of vascular dysfunction is invasive evaluation of coronary flow reserve. Coronary flow reserve is an increase in blood flow in response to metabolic or pharmacological stimuli ${ }^{19}$. Diminished coronary reserve is an indicator of possible ischemia, which could be provoked by increase in myocardial oxygen demand. Results of the above mentioned test indicate that microvascular dysfunction is a plausible cause of CSX. Novel studies using magnetic resonance (MR) confirm decreased subendocardial perfusion in patients with CSX compared to healthy control group ${ }^{19}$. PET demonstrated diminished coronary reserve in $50 \%$ to $60 \%$ of female patients with non-CAD, and MRI in $25 \%$ of the same population ${ }^{19}$. However, the prevalence of ischemia is probably underestimated with MR considering the limited ability to induce stress or exertion during $\mathrm{MR}^{20}$.
Obviously, microvascular dysfunction is a very important mechanism in the development of non-CAD. Primary disorder in microvascular dysfunction is altered (decreased) vasodilative response to adequate stimuli, but in a specific group of patients enhanced vasoconstrictory response can be present ${ }^{21}$.

Decreased endothelial dependent vasodilation (endothelial dysfunction) is diagnosed with provocation tests using acetylcholine or with direct electrostimulation of the right atrium, while non-endothelial dependent dysfunction can be established by adenosine, pyridamole or papaverine provocation tests ${ }^{21,22}$. Abnormal vasoconstriction can be confirmed by provocation with ergonovine, cold, hyperventilation, handshake test and acetylcholine ${ }^{23}$. After performing one of these provocation tests, diminished coronary reserve should be diagnosed with one of the previously mentioned methods (indirectly invasive - coronary flow reserve test or noninvasive tests - PET, MR).

Based on the results of our recently published research ${ }^{24}$, we propose a new mechanism that could be added to endothelial independent mechanisms within the ischemic hypothesis on the development of nonCAD. Alongside the known endothelial independent pathophysiological mechanisms such as aortic pressure, myocardial contractility, myocardial metabolism and neurohumoral factors ${ }^{25}$, another possible contributor would be the type of coronary supply, specifically the left type of dominance (particularly in women), and absence of mixed type in $\mathrm{men}^{24}$.

\section{Non-ischemic hypothesis}

Non-ischemic hypothesis explains the CSX phenomenon and non-CAD because of altered pain perception ${ }^{25}$. Previous studies demonstrated that patients with angina and normal coronary arteries had enhanced pain perception to heat and electrical stimuli ${ }^{26}$. There is evidence supporting the absence of habituation to frequent pain stimuli in these patients (habitual theory $)^{27}$. Furthermore, it is well known that estrogen has analgesic properties, which are mediated through opioid system, thus explaining the presence of chest pain in postmenopausal women with normal coronarography. It is possible that the lack of estrogen in females participates in altered chest pain perception $^{28}$.

In 1988, Shapiro et al. demonstrated that intracardial stimulation by infusion of saline to the right atri- 


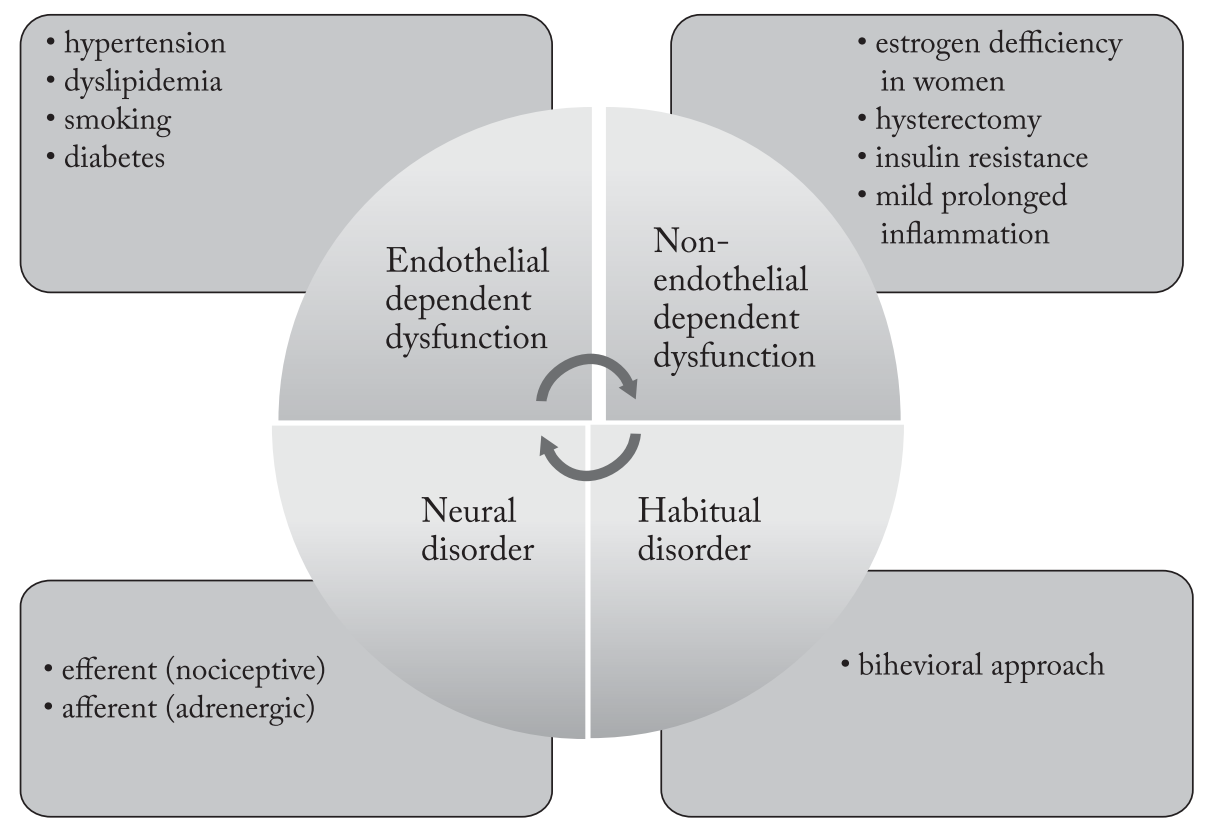

Fig. 1. Risk factors for development of non-CAD. There is a relationship between ischemic (endothelial and non-endothelial dependent theory) and non-ischemic (neural and habitual theory) risk factors. Repeated episodes of micro ischemia due to microvascular coronary dysfunction could lead to neural disorder affecting adrenergic or nociceptive fibers through fibrosis and mild prolonged inflammation. Habitual and neural theory could also be connected.

um induced chest pain in patients with angina and normal coronary arteries ${ }^{29}$. It was the first paper published that explained this phenomenon using altered pain perception. Although results of previous studies indicated generally diminished tolerance to all pain stimuli in these patients, the study by Iannetti et al. denied such notion ${ }^{30}$. Earlier studies were poorly controlled and badly designed, whereas new studies with laser pain stimuli on the skin surface established unaltered general pain perception. In addition, local electrostimulation of the right ventricle with higher frequencies demonstrated altered pain perception in the heart ${ }^{30}$.

Rosen et al. demonstrated that activation of the right frontal insula of the brain cortex in patients with CSX and ST changed during dobutamine stress test, suggesting cortical origin of this disorder ${ }^{31}$. Afferent (sympathetic) and efferent (nociceptive) fibers can be affected as well ${ }^{31}$. Enrolment of the sympathetic heart system (afferent component) can be clinically diagnosed by metaiodobenzylguanidine (MIBG) scintigraphy. In patients with CSX, radionuclide ${ }^{123}$ I- MIBG uptake is completely absent, although the liver and lung are clearly visible. This implicates significant ab- normality in sympathetic heart innervation in patients with non-CAD ${ }^{32}$. Involvement of efferent (nociceptive) fibers is established directly with electrostimulation of the right heart or pharmacologically with dobutamine or adenosine delivered locally as intracardial infusion ${ }^{31}$.

\section{Integrated ischemic and non-ischemic hypothesis}

It is currently presumed that the pathophysiological relationship between ischemic and non-ischemic hypothesis exists. Microvascular dysfunction and repeated subclinical episodes of ischemia could lead to structural changes in heart innervation through fibrosis or prolonged mild inflammation. This is presented as an enhanced pain perception to harmless local stimuli (efferent innervation) or as a decreased uptake of MIBG in sympathetic heart fibers, which implicates involvement of afferent fibers ${ }^{32}$.

Traditional risk factors such as hypertension, hypercholesterolemia and diabetes have a significant role in the development of microvascular dysfunction through endothelial dependent vasodilatation (endothelial dysfunction) and are part of ischemic hypothe$\operatorname{sis}^{33}$. Insulin resistance and glucose intolerance are also 
associated with endothelial dysfunction ${ }^{34}$. The lack of estrogen in females and hysterectomy are part of the non-ischemic hypothesis based on analgesic properties of estrogen ${ }^{35}$, while mild inflammation with increased concentration of $\mathrm{C}$-reactive protein and interleukin-1 receptor antagonists is a possible risk factor in nonischemic and ischemic hypothesis causing structural changes of neural fibers ${ }^{36}$ (Fig. 1).

\section{Diagnosis of Nonobstructive Coronary Artery Disease}

Diagnosis of non-CAD is based on clinical presentation and diagnostic procedures. Clinical presentation of angina can be more or less typical. Diagnostic tests in non-CAD can be invasive and noninvasive (Table 1).

Table 1. Diagnostic tests (invasive and noninvasive) in nonobstructive coronary artery disease (non-CAD)

\begin{tabular}{|c|l|}
\hline Clinical presentation & $\cdot$ Chest pain (anginal) \\
$\downarrow$ & $\cdot$ Exclusion of other \\
Conditions \\
Stress test positive & $\cdot$ Stress test \\
$\downarrow$ & $\cdot$ Myocardial scintigraphy \\
Coronary angiography & $\cdot$ Coronarography \\
$<50 \%$ stenosis & $\cdot$ MSCT \\
$\downarrow$ & \\
Non-CAD & Possible acetylcholine \\
& or ergonovine \\
& test (vasospasm) \\
\hline
\end{tabular}

MSCT $=$ multi-slice computed tomography

It is very important to emphasize that non-CAD is diagnosed by exclusion ${ }^{6}$. Exclusion of all other noncardiac causes of angina such as musculoskeletal pain, gastrointestinal disorders, pulmonary causes and various psychiatric disorders is necessary. In patients with probable angina, noninvasive diagnostic tests are performed trying to confirm ischemia through significant ST-T changes (based on established standardized diagnostic criteria) mostly during exertion. The basic test of physical activity is ergometry or exercise myocardial perfusion scintigraphy ${ }^{37}$.

Currently, there are no defined criteria for differentiating obstructive from nonobstructive disease in $\mathrm{pa}^{-}$ tients with positive stress test ${ }^{38}$. However, some authors suggest several criteria such as increased pressure and pulse pressure product during stress needed to cause $\mathrm{ST}$ changes in patients with non-CAD ${ }^{39}$.

Therefore, patients with positive stress test are candidates for further invasive diagnostic work-up to confirm or exclude obstructive changes of coronary arteries. Usually, direct catheterization of arteries (coronarography) is performed, although there are other noninvasive methods such as multi-slice computerized tomography (MSCT) ${ }^{6}$.

Some authors suggest acetylcholine or ergonovine test (intracoronary or intravenously) in patients with normal coronarography to exclude spasm of major arteries. Unfortunately, this procedure is highly risky due to the possibility of strong vasospasm and hypotension, thus it is not part of routine clinical work-up ${ }^{6}$.

After exclusion of all non-cardiac causes, diagnosis of CAD is based on clinical presentation of chest pain and diagnostic procedures. First procedure is noninvasive test of physical activity (ergometry, or rarely myocardial stress scintigraphy). In patients with positive stress test, coronarography is performed to definitely confirm or exclude obstructive stenosis ( $\geq 50 \%)$ of epicardial arteries. Spasm of major arteries can be diagnosed with ergonovine or acetylcholine test but due to the considerable risk it is not part of routine clinical work-up ${ }^{37}$.

Routine clinical work-up ends at this point. Additional tests for more accurate diagnosis of non-CAD are used only for research purposes ${ }^{6}$. In patients with suspected ischemic etiology (microvascular dysfunction), some pharmacological tests can be performed to confirm altered vasodilatation or enhanced vasoconstriction. The most commonly performed tests are acetylcholine test or electrostimulation to establish endothelial dependent dysfunction and adenosine, pyridamole or papaverine tests to establish non-endothelial dependent dysfunction. Vasoconstriction can be diagnosed with ergonovine test or cold pressure test ${ }^{23}$. After implementation of one of these tests, establishing induced ischemia in the microvasculature area $(<500 \mu \mathrm{m})$ is necessary ${ }^{8}$.

Since small blood vessels cannot be displayed on coronarography, ischemia is indirectly visualized with invasive methods such as the test of coronary flow reserve (CFR) or with noninvasive methods such as myocardial scintigraphy, MR or PET ${ }^{19,20}$.

To confirm non-ischemic origin of the disorder (altered pain perception), MIBG scintigraphy of sym- 
Table 2. Additional tests for exact identification of the extent of non-obstructive coronary artery disease

\begin{tabular}{|c|c|c|c|c|}
\hline \multicolumn{3}{|c|}{ Clinical condition } & \multicolumn{2}{|c|}{ Diagnostic tests } \\
\hline \multirow[t]{2}{*}{$\begin{array}{l}\text { Ischemic } \\
\text { mechanisms }\end{array}$} & \begin{tabular}{|l} 
Reduced \\
vasodilation
\end{tabular} & $\begin{array}{l}\text { Endothelium } \\
\text { dependent } \\
\text { Endothelium } \\
\text { independent }\end{array}$ & \multicolumn{2}{|c|}{$\begin{array}{l}\text { - Acetylcholine } \\
\text { - Electrostimulation } \\
\text { - Adenosine } \\
\text { - Pyridamole } \\
\text { - Papaverine }\end{array}$} \\
\hline & \multicolumn{2}{|c|}{ Increased vasoconstriction } & \multicolumn{2}{|c|}{$\begin{array}{l}\text { - Ergonovine } \\
\text { - Acetylcholine } \\
\text { - Exposure to cold }\end{array}$} \\
\hline \multirow[t]{3}{*}{$\begin{array}{l}\text { Non-ischemic } \\
\text { mechanisms }\end{array}$} & \multirow[t]{2}{*}{$\begin{array}{l}\text { Neurogenic } \\
\text { disorder }\end{array}$} & $\begin{array}{l}\text { Afferent } \\
\text { (adrenergic) }\end{array}$ & \multicolumn{2}{|c|}{ MIBG myocardial scintigraphy } \\
\hline & & $\begin{array}{l}\text { Efferent } \\
\text { (nociceptive) }\end{array}$ & $\begin{array}{l}\text { Pharmacological } \\
\text { Mechanical }\end{array}$ & $\begin{array}{l}\text { Dobutamine } \\
\text { Electrostimulation }\end{array}$ \\
\hline & \multicolumn{2}{|c|}{ Habitual disorder } & \multicolumn{2}{|c|}{ Psychological testing } \\
\hline \multicolumn{3}{|c|}{$\begin{array}{l}\text { Decreased coronary reserve } \\
(<500 \mu \mathrm{m})\end{array}$} & $\begin{array}{l}\text { Invasive } \\
\text { Noninvasive }\end{array}$ & $\begin{array}{l}\text { CFR } \\
\text { - Myocardial scintigraphy } \\
\text { - MR } \\
\text { - PET }\end{array}$ \\
\hline
\end{tabular}

$\mathrm{MIBG}={ }^{123} \mathrm{I}$-methaiodobenzylguanidine; $\mathrm{CFR}=$ coronary flow reserve; $\mathrm{MR}=$ magnetic resonance; $\mathrm{PET}=$ positron emission tomography

pathetic heart innervation for visualizing afferent dysfunction and direct heart stimulation with dobutamine or electrostimulator for demonstrating efferent dysfunction can be performed ${ }^{25}$. Additional tests are also available such as insufficiently standardized psychological tests for establishing habitual component of disorder, as well as absence of adaptation to repeated pain stimuli ${ }^{27}$. All additional diagnostic tests are summarized in Table 2.

\section{Prognosis of Nonobstructive Coronary Artery Disease and Prevalence of Major Cardiovascular Outcomes}

Unlike former opinions, current studies have verified that patients with non-CAD have an increased risk of cardiac mortality ${ }^{11,40,41}$. Prognosis of non-CAD is not benign considering $2 \%$ risk of cardiac death or myocardial infarction within 30 days of disease manifestation ${ }^{11}$. Several studies demonstrated that advanced coronary atheroma could be present despite normal or almost normal coronary arteries ${ }^{42}$, thus increasing the risk of adverse acute events ${ }^{43}$. The Women's Ischemia Syndrome Evaluation (WISE) trial, which included women with non-CAD, demonstrated that different symptom profiles were associated with different long- term outcomes ${ }^{44}$. An increase in adverse cardiac events was observed in patients with non-CAD. These findings suggest that normal or almost normal coronary arteries on coronarography do not imply benign prognosis ${ }^{44}$.

Furthermore, classic definition of coronary disease symptoms encompasses retrosternal chest pain or discomfort (which can irradiate into the neck, arm, jaw and back), with pain quality described as dull, sharp, crushing or burning, lasting for 2-20 minutes and worsened with physical activity, while alleviated with rest or nitroglycerin ${ }^{45}$. On the other hand, the majority of patients (around 70\%) in the study performed by Johnson et al. ${ }^{44}$ presented with atypical symptoms regardless of verified nonobstructive or obstructive coronary disease on coronarography. As a consequence of this symptom variability, patients with atypical presentation and an increased risk of adverse cardiac events can be easily overlooked. Previous studies performed in patients with angina and normal coronarography in the 1960s did not demonstrate an increased prevalence of adverse clinical events, or increased mortality ${ }^{46}$. Those studies were performed in a small number of patients with short follow-up; therefore, the increased risk in those patients was not determined ${ }^{47}$. The WISE trial was the first study that demonstrated completely 
opposite results in females with CSX. Those patients had a three-fold higher prevalence of adverse cardiovascular events (including heart failure and stroke) compared to healthy controls during the 5-year follow-up $(2.4 \% \text { vs. } 7.9 \% \text {; } \mathrm{p}=0.002)^{44}$. These results were confirmed by the British Columbia registry, which established a 4 times higher probability of hospital readmission in females with angina and nonobstructive changes on coronarography presenting as acute coronary syndrome compared to males during early follow-up ${ }^{48}$.

However, the WISE trial was not successful in establishing statistically higher prevalence of myocardial infarction or cardiac death compared to healthy population, despite numerical differences. Nevertheless, the total mortality rate was significantly higher compared to the control group $(2.1 \% \text { vs. } 3.0 \% ; \mathrm{p}=0.04)^{44}$. This observation is extremely important since a high mortality rate was established for the first time in women with non-CAD. It is considered that prognosis in females with non-CAD depends on microvascular dysfunction ${ }^{49}$. Several studies demonstrated that patients with CSX and established microvascular dysfunction had a higher probability of developing CAD in the future and higher prevalence of adverse cardiovascular events ${ }^{50}$. Moreover, investigators in the WISE trial additionally stratified patients with nonobstructive disease in two groups. First group consisted of patients with confirmed ischemia using MR spectroscopy (indirect proof of microvascular dysfunction), whereas in the second group of patients diagnosis of ischemia with that method was not possible. In the group of patients with confirmed ischemia and microvascular dysfunction, a higher prevalence of adverse cardiovascular events was observed even when considering all traditional risk factors ${ }^{44}$. The WISE trial included only women, thus it is still unclear whether the same observations apply to male population.

In 2012, Jespersen et al..$^{51}$. published results from the Copenhagen City Heart trial including 11,233 patients that underwent coronarography due to the symptoms of stable angina and were compared to healthy individuals without cardiovascular events. Significantly more females (65\%) compared to males (32\%) had non-CAD among patients with stable coronary disease. This is consistent with the observations from the WISE trial that $62 \%$ of patients who underwent coronarography due to chest pain had non-CAD.
The Danish trial was designed as a retrospective cohort study including all patients from eastern Denmark that underwent coronarography due to angina from 1998 to $2009^{51}$. This trial demonstrated that both males and females with anginal symptoms and normal or nonobstructive changes of coronary arteries had an increased risk of adverse cardiovascular events compared to healthy population without ischemic events. That specific group of patients with normal coronary arteries or nonobstructive changes of coronary arteries had $52 \%$ and $85 \%$ increased risk of major adverse cardiac events (MACE) including cardiac death, hospitalization due to myocardial infarction and heart failure or stroke, and 29\% and 52\% had an increased mortality risk regardless of the cause. There was no statistically significant difference for MACE or mortality rate between men and women ${ }^{51}$.

\section{Treatment of Nonobstructive Coronary Artery Disease}

Treatment of non-CAD presents a great challenge. Unfortunately, therapy is often unsuccessful because symptoms persist at 5 -year follow-up in almost $50 \%$ of treated women ${ }^{54}$. There are few medications and procedures that are undoubtedly efficient in CSX treatment. Experiences gathered from large clinical trials are lacking. Most of observations and conclusions are based on smaller and observational studies that included only a few dozens of patients or less. Results of those trials are mostly contradictory or lacking well defined control groups for comparison. The Effects of Allopurinol on Coronary and Peripheral Endothelial Function in Patients with Cardiac Syndrome X (APEX) trial is one of the few clinically controlled pending trials (started in 2008) that is trying to evaluate specific drug efficacy, in this case allopurinol, in treating $\mathrm{CSX}^{55}$. However, based on the current knowledge, it is safe to say that beta-blockers and lifestyle changes modifying cardiovascular risk factors have a central role in non-CAD treatment ${ }^{55}$. All therapeutic measures in non-CAD treatment can be divided into medicamentous and non-medicamentous measures that are summarized in Table 3.

\section{Medicamentous measures}

There are numerous small trials demonstrating atenolol efficacy in CSX treatment ${ }^{56-58}$. Atenolol 
Table 3. Therapeutic recommendations for treatment of non-obstructive coronary artery disease

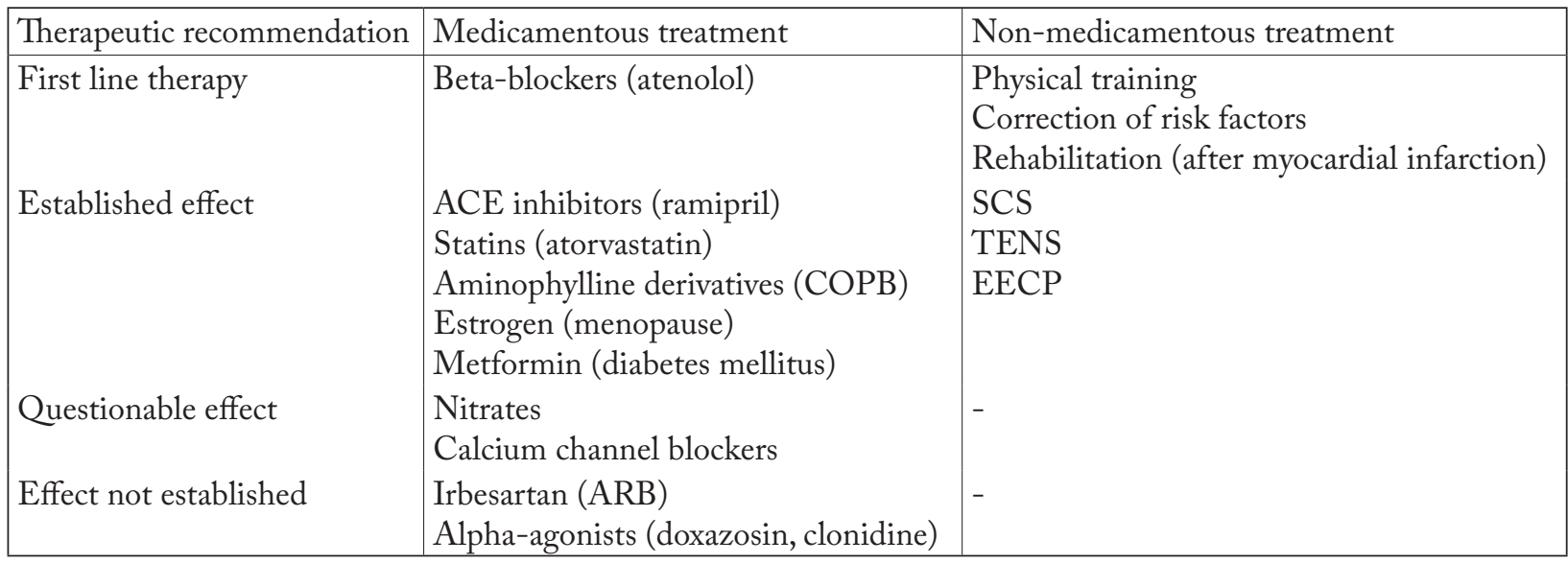

$\mathrm{ACE}=$ angiotensin-converting enzyme $\mathrm{COPB}=$ chronic obstructive pulmonary disease; $\mathrm{SCS}=$ spinal cord stimulation; TENS = transdermal electric nerve stimulation; EECP = extracorporeal enhanced counter pulsation; $\mathrm{ARB}=$ angiotensin II receptor blockers

decreases pain, improves coronary reserve, and decreases ST depression during exertion test ${ }^{56}$. The calcium channel blockers verapamil and amlodipine were not efficient compared to atenolol, although there are some reports indicating beneficial effect of atenolol and amlodipine combination ${ }^{56}$. Unfortunately, controlled experiences with other beta-blockers are lacking. Nebivolol is the only drug investigated in patients with non-CAD. Nebivolol is a highly selective beta1-blocker with beneficial effect on endothelial function, which increases bioavailability of the most potent endogenous vasodilator $\mathrm{NO}^{55}$. Upon intracoronary infusion, it increases coronary reserve in patients with and without obstructive changes in the epicardial arteries. However, intracoronary application of this drug is not clinically possible, while experiences with oral usage are still lacking.

Investigators generally agree that beta-blockers have beneficial effect, although there is a response variability of $19 \%-60 \%{ }^{59}$. However, based on current research, beta-blockers (especially atenolol) should be the first line treatment in patients with $\mathrm{CSX}^{60}$.

Although expected, efficacy of nitrates in CSX treatment is still questionable. In small observational studies, efficacy was present in only $42 \%$ of patients. Moreover, there are some reports indicating decreased tolerance during the test of physical activity in those patients when treated with nitrates ${ }^{61}$. Therefore, nitrates are recommended exclusively in combination with other efficient drugs ${ }^{56}$.
The xanthine derivatives aminophylline and theophylline are blocking adenosine receptors, thus enabling more favorable redistribution of coronary flow and probably blocking adenosine effect in pain provocation (intracoronary infusion of adenosine elicits chest pain in patients with CSX) ${ }^{6,55}$. Intravenous or oral administration of aminophylline during the test of physical activity increases exercise tolerance, diminishes pain perception, and decreases ST changes ${ }^{62,63}$. Therefore, these medications can be recommended, especially in patients treated for asthma or chronic obstructive pulmonary disease ${ }^{55}$.

In small observational and placebo controlled trials, some angiotensin-converting enzyme (ACE) inhibitors had certain beneficial effect ${ }^{64}$, this referring to cilazapril $^{65}$, enalapril ${ }^{66}$ and a combination of ramipril and statin (atorvastatin) ${ }^{55}$. Antagonists of angiotensin receptors (ARB), despite expectations, did not demonstrate any favorable effects in a trial investigating irbe$\operatorname{sartan}^{67}$. For other members of this group, efficacy was neither investigated nor established.

In several studies, statins showed some efficacy in treating CSX, probably due to their anti-inflammatory effect. The effect was present regardless of the plasma lipid profile baseline values ${ }^{68,69}$. Furthermore, additional synergic effect was established with some ACE inhibitors, especially for atorvastatin and ramipril ${ }^{6,55,68}$.

Of all other medications utilized in CSX treatment that had certain success, we should mention estrogen in postmenopausal women ${ }^{55,70}, \mathrm{~L}$-arginine (precursor 
Table 4. Suggested classification of pathophysiological mechanisms in nonobstructive coronary artery disease (non-CAD)

\begin{tabular}{|c|c|c|c|c|}
\hline \multicolumn{2}{|c|}{ Type of non-CAD disorder } & \multicolumn{2}{|c|}{ Underlying mechanism } & Clinical presentation \\
\hline Type I & $\begin{array}{l}\text { Ischemic } \\
\text { mechanisms }\end{array}$ & $\begin{array}{l}1 \mathrm{~A} \\
1 \mathrm{~B}\end{array}$ & $\begin{array}{l}\text { Endothelium dependent } \\
\text { reduced vasodilation } \\
\text { Endothelium independent } \\
\text { reduced vasodilation }\end{array}$ & $\begin{array}{l}\text { Endothelial dysfunction } \\
\text { - Aortic pressure } \\
\text { - Myocardial contractility } \\
\text { - Myocardial metabolism } \\
\text { - Neurohumoral factors } \\
\text { - Type of coronary artery supply } \\
\text { Vasospasm }\end{array}$ \\
\hline Type II & $\begin{array}{l}\text { Non-ischemic } \\
\text { mechanisms }\end{array}$ & $\begin{array}{l}2 \mathrm{~A} \\
2 \mathrm{~B} \\
2 \mathrm{C}\end{array}$ & $\begin{array}{l}\text { Neurogenic afferent } \\
\text { Neurogenic efferent } \\
\text { Habitual }\end{array}$ & $\begin{array}{l}\text { Adrenergic disorder } \\
\text { Nociceptive disorder } \\
\text { Behavioral disorder }\end{array}$ \\
\hline
\end{tabular}

of vasodilator $\mathrm{NO})^{71,72}$, metformin in patients with glucose intolerance ${ }^{73}$, and imipramine that is used in the treatment of chronic pain ${ }^{74,75}$.

The efficacy of $\alpha$-antagonists (doxazosin and clonidine) has not yet been established in the treatment of non-CAD symptoms ${ }^{76}$.

There are several new drugs with probable therapeutic effect in CSX based on their mechanism of action. However, currently there is no strong evidence to confirm their efficacy and justify their application. Some of these drugs are bosentan (ET-1 inhibitor), cariporid (Na-H+ exchanger), fasudil (rho-kinase inhibitor) and trimetazidine (metabolic antianginal drug $)^{55}$. Only nicorandil, activator of vascular potassium channels with vasodilatory abilities, is effective in the treatment of microvascular coronary disease $\mathrm{e}^{77,78}$.

\section{Non-medicamentous measures}

Besides the above mentioned pharmacological measures in the treatment of CSX symptoms, there are also non-medicamentous procedures that exhibited favorable effect in some patients. Spinal cord stimulation (SCS) with low voltage electric impulses affects pain modulation and diminishes pain sensation in patients with angina ${ }^{79}$. This method is approved in the treatment of refractory angina in patients with CAD unsuitable for revascularization, and has class IIb recommendation according to the American College of Cardiology/American Heart Association (AHA/ACC) guidelines ${ }^{80}$. There are several reports indicating efficacy of this method in long-term control of symptoms in patients with $\mathrm{CSX}^{79,81}$.
Similar procedure is transdermal electric nerve stimulation (TENS). This procedure improves coronary flow without altering microvasculature diameter and has beneficial effect in eliminating symptoms ${ }^{82-84}$.

Extracorporeal enhanced counter pulsation (EECP) consists of periodical inflating and deflating pressure cuffs on lower extremities that proved efficient in recovering endothelial function and in some small studies led to diminishing anginal symptoms ${ }^{85}$.

Lifestyle modifications and affecting cardiovascular risk factors are basic recommendations for patients with non-CAD ${ }^{55}$. Physical exercise improves coronary reserve and exercise tolerance, and diminishes symptoms in both $\mathrm{CAD}$ and non-CAD ${ }^{86}$. Additional improvement of exercise tolerance, quality of life, and beneficial effect on anginal symptoms can be achieved through rehabilitation ${ }^{87,88}$. Recommendations are weight reduction ${ }^{89}$, smoking cessation ${ }^{90}$ and low fat or Mediterranean $\operatorname{diet}^{91}$, which improves endothelial dysfunction $^{55}$.

\section{New Classification of Nonobstructive Coronary Artery Disease Suggested}

We propose here a new classification of non-CAD, separating the whole syndrome in type I (ischemic disease) and type II (non-ischemic disease), based on which clinical syndrome predominates. Each of these is further divided based on the existing mechanism and is marked by letters A, B or C, as shown in Table 4 .

Disorder $1 \mathrm{~A}$ represents endothelial dependent reduced vasodilatation, which clinically corresponds to 
endothelial dysfunction. Established cardiovascular risk factors such as smoking, dyslipidemia, diabetes mellitus or hypertension are involved in the pathophysiology of this mechanism, as well as NO, enothelin-1, and other anti-inflammatory and antithrombotic factors. Disorder 1B represents endothelial independent mechanisms. Clinically, this includes aortic pressure, myocardial contractility, myocardial metabolism, neurohumoral factors, and type of coronary artery supply. As previously highlighted, left dominance in women is more frequent in non-CAD, as well as the absence of mixed dominance in men. Disorder $1 \mathrm{C}$ represents increased vasoconstriction. This mechanism contains both microvascular and macrovascular (vasospastic) vasoconstriction, but without permanent obstruction of coronary arteries $>50 \%$. In a broader sense, this refers to the bridging of coronary arteries as well, which represents dynamic stenosis in the location where major coronary artery is running intramyocardially. This is mostly seen in the left anterior descending artery, but may be seen in other coronary arteries as well.

Non-ischemic mechanisms may also be divided into three basic groups, and are marked by letters A, B and $\mathrm{C}: 2 \mathrm{~A}$ is a neurogenic afferent mechanism, which clinically represents adrenergic disorder of heart innervation; $2 \mathrm{~B}$ is neurogenic efferent mechanism that clinically represents nociceptive disorder; and $2 \mathrm{C}$ is habitual mechanism that represents behavioral disorder.

In clinical practice, the same patient may have more of less combined induced mechanisms. However, there is always one predominant mechanism in clinical presentation of non-CAD, and the disorder can be classified by that predominant mechanism.

Certainly, microvascular dysfunction plays a significant role in the development of non-CAD, but other mechanisms should not remain unattended. These pathophysiological mechanisms are well defined and lead to anginal symptoms, and affect major coronary arteries, not the microvasculature. This especially refers to vasospastic, Prinzmetal's angina, and phenomenon of myocardial bridging. Both affect major coronary arteries and should be placed among the mechanisms of non-CAD.

With this new classification, the aim is to include all the known pathophysiological mechanisms and align classification to current diagnostic testing, thus hopefully contributing to better understanding, timely diagnosis and comprehensive management of nonCAD.

\section{References}

1. Monteiro J. Angina pectoris with normal coronary arteries. Acta Med Port. 1997;10:283-5.

2. Banks K, Lo M, Khera A. Angina in women without obstructive coronary artery disease. Curr Cardiol Rev. 2010;6:71-81. doi: $10.2174 / 157340310790231608$.

3. Kemp HG Jr, Vokonas PS, Cohn PF, et al. The anginal syndrome associated with normal coronary arteriograms. Report of a six-year experience. Am J Med. 1973;54:735-42.

4. Melikian N, De Bruyne B, Fearon WF, MacCarthy PA. The pathophysiology and clinical course of the normal coronary angina syndrome (cardiac syndrome X). Prog Cardiovasc Dis. 2008;50:294-310.DOI: 10.1016/j.pcad.2007.01.003.

5. Lanza GA. Cardiac syndrome X: a critical overview and future perspectives. Heart. 2007;93:159-66. doi: 10.1136/hrt.2005.067330.

6. Crea F, Lanza GA. Angina pectoris and normal coronary arteries: cardiac syndrome X. Heart. 2004;90:457-63.

7. Brush JE Jr, Cannon RO $3^{\text {rd }}$, Schenke WH, et al. Angina due to coronary microvascular disease in hypertensive patients without left ventricular hypertrophy. N Engl J Med. 1988;319: 1302-7.

8. Cannon RO, Epstein SE. "Microvascular angina" as a cause of chest pain with angiographically normal coronary arteries. Am J Cardiol. 1988;61:1338-43.

9. Kaski JC, Russo GZ. Microvascular angina in patients with syndrome X. Z Kardiol. 2000; 89:121-5.

10. Kothawade K, Bairey Merz CN. Microvascular coronary dysfunction in women - pathophysiology, diagnosis, and management. Curr Probl Cardiol. 2011;36:291-318.

Doi: 10.1016/j.cpcardiol.2011.05.002.

11. Bugiardini R, Bairey Merz CN. Angina with "normal" coronary arteries. JAMA. 2005;293:477-84.

DOI: 10.1001/jama.293.4.477.

12. Phibbs B, Fleming T, Ewy GA, et al. Frequency of normal coronary adenosine receptors or sensitivity may account for regional arteriograms in three academic medical centers and one community myocardial perfusion abnormalities hospital. Am J Cardiol. 1988;62:472-4.

13. Hurst T, Olson TH, Olson LE, et al. Cardiac syndrome $X$ and endothelial dysfunction: new concepts in prognosis and treatment. Am J Med. 2006;119:560-6.

DOI: 10.1016/j.amjmed.2005.07.009.

14. Herrmann J, Kaski JC, Lerman A. Coronary microvascular dysfunction in the clinical setting: from mystery to reality. Eur Heart J. 2012;33:2771-82b.

15. Maseri A, Crea F, Kaski JC, et al. Mechanisms of angina pectoris in syndrome X. J Am Coll Cardiol. 1991;17:499-506. DOI: org/10.1016/S0735-1097(10)80122-6. 
16. Buchthal SD, den Hollander JA, Merz CN, et al. Abnormal myocardial phosphorus-31 nuclear magnetic resonance spectroscopy in women with chest pain but normal coronary angiograms. N Engl J Med. 2000;342:829-35.

DOI:10.1056/NEJM200003233421201.

17. Rosen SD, Paulesu E, Wise RJ, et al. Central neural contribution to the perception of chest pain in cardiac syndrome $\mathrm{X}$. Heart. 2002;87:513-9.

18. Kaski JC, Cox ID, Crook JR, et al. Differential plasma endothelin levels in subgroups of patients with angina and angiographically normal coronary arteries. Coronary Artery Disease Research Group. Am Heart J. 1998;136:412-7.

19. Rasmi Y, Mehraban K, Sadreddini M, et al. Lack of significant association between Helicobacter pylori infection and homocysteine levels in patients with cardiac syndrome X. Cardiol J. 2012;19:466-9.

20. Panting JR, Gatehouse PD, Yang GZ, et al. Abnormal subendocardial perfusion in cardiac syndrome $\mathrm{X}$ detected by cardiovascular magnetic resonance imaging. N Engl J Med. 2002; 346:1948-53. DOI: 10.1056/NEJMoa012369.

21. Doyle M, Fuisz A, Kortright E, et al. The impact of myocardial flow reserve on the detection of coronary artery disease by perfusion imaging methods: an NHLBI WISE study. J Cardiovasc Magn Reson. 2003;5:475-85.

DOI: 10.1081/JCMR-120022263.

22. Cox ID, Botker HE, Bagger JP, et al. Elevated endothelin concentrations are associated with reduced coronary vasomotor responses in patients with chest pain and normal coronary arteriograms. J Am Coll Cardiol. 1999;34:455-60.

23. Hoffmann E, Assennato P, Donatelli M, et al. Plasma endothelin-1 levels in patients with angina pectoris and normal coronary angiograms. Am Heart J. 1998;135:684-8.

24. Chauhan A, Mullins PA, Taylor G, et al. Both endotheliumdependent and endothelium-independent function is impaired in patients with angina pectoris and normal coronary angiograms. Eur Heart J. 1997;18:60-8.

25. Makarovic Z, Makarovic S, Bilic-Curcic I. Sex-dependent association between coronary vessel dominance and cardiac syndrome X: a case-control study. BMC Cardiovasc Disord. 2014 Oct 9;14:142. doi: 10.1186/1471-2261-14-142.

26. Cannon RO $3^{\text {rd }}$, Quyyumi AA, Schenke WH, et al. Abnormal cardiac sensitivity in patients with chest pain and normal coronary arteries. J Am Coll Cardiol. 1990;16:1359-66.

27. Cannon RO $3^{\text {rd }}$. The sensitive heart. A syndrome of abnormal cardiac pain perception. JAMA. 1995;273:883-7.

28. Valeriani M, Sestito A, Le Pera D, et al. Abnormal cortical pain processing in patients with cardiac syndrome X. Eur Heart J. 2005;26:975-82.

29. Rosano GM, Peters NS, Lefroy D, et al. 17-beta-estradiol therapy lessens angina in postmenopausal women with syndrome X. J Am Coll Cardiol. 1996;28:1500-5.

30. Shapiro LM, Crake T, Poole-Wilson PA. Is altered cardiac sensation responsible for chest pain in patients with normal coro- nary arteries? Clinical observation during cardiac catheterisation. Br Med J (Clin Res Ed). 1988;296:170-1.

31. Iannetti GD, Zambreanu L, Cruccu G, et al. Operculoinsular cortex encodes pain intensity at the earliest stages of cortical processing as indicated by amplitude of laser-evoked potentials in humans. Neuroscience. 2005;131:199-208.

DOI: 10.1016/j.neuroscience.2004.10.035.

32. Rosen SD, Paulesu E, Wise RJ, et al. Central neural contribution to the perception of chest pain in cardiac syndrome $\mathrm{X}$. Heart. 2002 Jun;87:513-9.

33. Lanza GA, Giordano A, Pristipino C, et al. Abnormal cardiac adrenergic nerve function in patients with syndrome $\mathrm{X}$ detected by [123I]metaiodobenzylguanidine myocardial scintigraphy. Circulation. 1997;96:821-6.

34. Kaski JC,Aldama G, Cosín-Sales J. Review: Cardiac syndrome $\mathrm{X}$. Diagnosis, pathogenesis and management. Am J Cardiovasc Drugs. 2004;4:179-94. DOI: 10.2165/00129784-200404030-00005.

35. Bøtker HE, Frøbert O, Møller N, et al. Insulin resistance in cardiac syndrome $\mathrm{X}$ and variant angina: influence of physical capacity and circulating lipids. Am Heart J. 1997;134:229-37.

36. Hayward CS, Kelly RP, Collins P. The roles of gender, the menopause and hormone replacement on cardiovascular function. Cardiovasc Res. 2000;46:28-49.

37. Lanza GA, Sestito A, Cammarota G, et al. Assessment of systemic inflammation and infective pathogen burden in patients with cardiac syndrome X. Am J Cardiol. 2004;94:40-4. DOI: 10.1016/j.amjcard.2004.03.027.

38. Kaski JC, Elliott PM. Angina pectoris and normal coronary arteriograms: clinical presentation and hemodynamic characteristics. Am J Cardiol. 1995;76:35D-42D.

39. Vermeltfoort IA, Raijmakers PG, Riphagen II, et al. Definitions and incidence of cardiac syndrome $\mathrm{X}$ : review and analysis of clinical data. Clin Res Cardiol. 2010;99:475-81. doi: 10.1007/s00392-010-0159-1.

40. Lanza GA, Sestito A, Iacovella S, et al. Relation between platelet response to exercise and coronary angiographic findings in patients with effort angina. Circulation. 2003;107:1378-82.

41. Bugiardini R. Women, 'non-specific' chest pain, and normal or near-normal coronary angiograms are not synonymous with favourable outcome. Eur Heart J. 2006;27:1387-9. doi:10.1371/journal.pmed.0040012.

42. Gulati M, Cooper-DeHoff R, McClure C, et al. Adverse cardiovascular outcomes in women with nonobstructive coronary artery disease. Arch Intern Med. 2009;169: 843-50. DOI: 10.1001/archinternmed.2009.50.

43. Erbel R, Ge J, Bockisch A, et al. Value of intracoronary ultrasound and Doppler in the differentiation of angiographically normal coronary arteries: a prospective study in patients with angina pectoris. Eur Heart J. 1996;17:880-9.

44. Sullivan AK, Holdright DR, Wright CA, et al. Chest pain in women: clinical, investigative, and prognostic features. BMJ. 1994;308:883-6. 
45. Johnson BD, Shaw LJ, Pepine CJ, et al. Persistent chest pain predicts cardiovascular events in women without obstructive coronary artery disease: results from the NIH-NHLBI-sponsored Women's Ischemia Syndrome Evaluation (WISE) study. Eur Heart J. 2006;27:1408-15.

DOI: 10.1093/eurheartj/eh1040.

46. Gibbons RJ, Chatterjee K, Daley J, et al. ACC/AHA/ACP ASIM guidelines for the management of patients with chronic stable angina: a report of the American College of Cardiology/ American Heart Association Task Force on practice guidelines (Committee on the Management of Patients with Chronic Stable Angina). J Am Coll Cardiol. 1999;33:2092-197.

47. Hirota Y, Ohnaka H, Tsuji R, et al. Excellent prognosis of Japanese patients with chest pain and normal or nearly normal coronary arteries - 2- to 13-year follow-up of 274 patients after coronary cineangiography. Jpn Circ J. 1994;58:43-8.

48. Bemiller CR, Pepine CJ, Rogers AK. Long-term observations in patients with angina and normal coronary arteriograms. Circulation. 1973;47:36-43.

49. Humphries KH, Pu A, Gao M, et al. Angina with 'normal' coronary arteries: sex differences in outcomes. Am Heart J. 2008;155:375-81. DOI: 10.1016/j.ahj.2007.10.019.

50. Hurst T, Olson TH, Olson LE, et al. Review. Cardiac syndrome $\mathrm{X}$ and endothelial dysfunction: new concepts in prognosis and treatment. Am J Med. 2006;119:560-6. DOI: 101016/j.amjmed.2005.07.009.

51. Suwaidi JA, Hamasaki S, Higano ST, et al. Long-term followup of patients with mild coronary artery disease and endothelial dysfunction. Circulation. 2000;101:948-54.

52. Jespersen L, Hvelplund A, Abildstrøm SZ, et al. Stable angina pectoris with no obstructive coronary artery disease is associated with increased risks of major adverse cardiovascular events. Eur Heart J. 2012;33:734-44. DOI: 10.1093/eurheartj/ehr331.

53. Pedersen S, Galatius S, Mogelvang R, et al. Long-term prognosis in an ST-segment elevation myocardial infarction population treated with routine primary percutaneous coronary intervention: from clinical trial to real-life experience. Circ Cardiovasc Interv. 2009;2:392-400.

DOI: 10.1161/CIRCINTERVENTIONS.108.845636.

54. Johnson BD, Shaw LJ, Buchthal SD, et al. Prognosis in women with myocardial ischemia in the absence of obstructive coronary disease: results from the National Institutes of Health-National Heart, Lung, and Blood Institute-sponsored Women's Ischemia Syndrome Evaluation (WISE). Circulation. 2004;109:2993-9. DOI: 10.1161/01.CIR.0000130642.79868.B2.

55. Shaw LJ, Merz CN, Pepine CJ, et al. The economic burden of angina in women with suspected ischemic heart disease: results from the National Institutes of Health-National Heart, Lung, and Blood Institute-sponsored Women's Ischemia Syndrome Evaluation. Circulation. 2006;114:894-904. DOI: 101161/CIRCULATIONAHA.105.609990.

56. Jones E, Eteiba W, Merz NB. Cardiac syndrome X and microvascular coronary dysfunction. Trends Cardiovasc Med. 2012; 22:161-8. DOI: 10.1016/j.tcm.2012.07.014.
57. Lanza GA, Colonna G, Pasceri V, et al. Atenolol versus amlodipine versus isosorbide-5-mononitrate on anginal symptoms in syndrome X. Am J Cardiol. 1999;84:854-6.A8.

58. Fragasso G, Chierchia SL, Pizzetti G, et al. Impaired left ventricular filling dynamics in patients with angina and angiographically normal coronary arteries: effect of beta adrenergic blockade. Heart. 1997;77:32-9.

59. Bugiardini R, Borghi A, Biagetti L, et al. Comparison of verapamil versus propranolol therapy in syndrome X. Am J Cardiol. 1989;63:286-90.

60. Kaski JC, Valenzuela Garcia LF. Therapeutic options for the management of patients with cardiac syndrome X. Eur Heart J. 2001;22:283-93. DOI: https://doi.org/10.15420/icr.2018.15.2.

61. Leonardo F, Fragasso G, Rossetti E, et al. Comparison of trimetazidine with atenolol in patients with syndrome X: effects on diastolic function and exercise tolerance. Cardiologia. 1999;44:1065-9.

62. Lanza GA, Manzoli A, Bia E, et al. Acute effects of nitrates on exercise testing in patients with syndrome X. Clinical and pathophysiological implications. Circulation. 1994;90: 2695-700.

63. Yoshio H, Shimizu M, Kita Y, et al. Effects of short-term aminophylline administration on cardiac functional reserve in $\mathrm{pa}^{-}$ tients with syndrome X. J Am Coll Cardiol. 1995;25:1547-51.

64. Radice M, Giudici V, Pusineri E, et al. Different effects of acute administration of aminophylline and nitroglycerin on exercise capacity in patients with syndrome X. Am J Cardiol. 1996; 78:88-92.

65. Kaski JC, Rosano G, Gavrielides S, et al. Effects of angiotensinconverting enzyme inhibition on exercise-induced angina and ST segment depression in patients with microvascular angina. J Am Coll Cardiol. 1994;23:652-7.

66. Nalbantgil I, Onder R, Altintig A, et al. Therapeutic benefits of cilazapril in patients with syndrome X. Cardiology. 1998;89: 130-3.

67. Chen JW, Hsu NW, Wu TC, et al. Long-term angiotensinconverting enzyme inhibition reduces plasma asymmetric dimethylarginine and improves endothelial nitric oxide bioavailability and coronary microvascular function in patients with syndrome X. Am J Cardiol. 2002;90:974-82.

68. Russell SJ, Di Stefano EM, Naffati MT, et al. The effects of the angiotensin II receptor (type I) antagonist irbesartan in patients with cardiac syndrome X. Heart. 2007;93:253-4.

69. Kayikcioglu M, Payzin S, Yavuzgil O, et al. Benefits of statin treatment in cardiac syndrome-X1. Eur Heart J. 2003;24: 1999-2005.

70. Fabian E, Varga A, Picano E, et al. Effect of simvastatin on endothelial function in cardiac syndrome $\mathrm{X}$ patients. Am J Cardiol. 2004;94:652-5. DI: 10.1016/jamjcard.2004.05.035.

71. Knuuti J, Kalliokoski R, Janatuinen T, et al. Effect of estradioldrospirenone hormone treatment on myocardial perfusion reserve in postmenopausal women with angina pectoris. Am J Cardiol. 2007;99:1648-52.

DOI: 10.1016/j.amjcard.2007.01.042. 
72. Piatti P, Fragasso G, Monti LD, et al. Acute intravenous L-arginine infusion decreases endothelin-1 levels and improves endothelial function in patients with angina pectoris and normal coronary arteriograms: correlation with asymmetric dimethylarginine levels. Circulation. 2003;107:429-36.

73. Palloshi A, Fragasso G, Piatti P, et al. Effect of oral L-arginine on blood pressure and symptoms and endothelial function in patients with systemic hypertension, positive exercise tests, and normal coronary arteries. Am J Cardiol. 2004;93:933-5. DOI: 10.1016/j.amjcard.2003.12.040.

74. Jadhav S, Ferrell W, Greer IA, et al. Effects of metformin on microvascular function and exercise tolerance in women with angina and normal coronary arteries: a randomized, doubleblind, placebo-controlled study. J Am Coll Cardiol. 2006;48: 956-63. DOI: 10.1016/j.acc.2006.04.088.

75. Cannon RO 3 ${ }^{\text {rd }}$, Quyyumi AA, Mincemoyer R, et al. Imipramine in patients with chest pain despite normal coronary angiograms. N Engl J Med. 1994;330:1411-7.

76. Cox ID, Hann CM, Kaski JC. Low dose imipramine improves chest pain but not quality of life in patients with angina and normal coronary angiograms. Eur Heart J. 1998;19:250-4.

77. Galassi AR, Kaski JC, Pupita G, et al. Lack of evidence for alpha-adrenergic receptor-mediated mechanisms in the genesis of ischemia in syndrome X. Am J Cardiol. 1989;64:264-9.

78. Yamabe H, Namura H, Yano T, et al. Effect of nicorandil on abnormal coronary flow reserve assessed by exercise 201T1 scintigraphy in patients with angina pectoris and nearly normal coronary arteriograms. Cardiovasc Drugs Ther. 1995;9:755-61.

79. Chen JW, Lee WL, Hsu NW, et al. Effects of short-term treatment of nicorandil on exercise-induced myocardial ischemia and abnormal cardiac autonomic activity in microvascular angina. Am J Cardiol. 1997;80:32-8.

80. Sgueglia GA, Sestito A, Spinelli A, et al. Long-term follow-up of patients with cardiac syndrome $\mathrm{X}$ treated by spinal cord stimulation. Heart. 2007;93:591-7.

DOI: $10.1136 /$ hrt.2006.102194.

81. Gibbons RJ, Abrams J, Chatterjee K, et al. ACC/AHA 2002 guideline update for the management of patients with chronic stable angina - summary article: a report of the American College of Cardiology/American Heart Association Task Force on practice guidelines (Committee on the Management of $\mathrm{Pa}$ tients with Chronic Stable Angina). J Am Coll Cardiol. 2003; 41:159-68.

82. Eliasson T, Albertsson $\mathrm{P}$, Hårdhammar $\mathrm{P}$, et al. Spinal cord stimulation in angina pectoris with normal coronary arteriograms. Coron Artery Dis. 1993;4:819-27.

83. Chauhan A, Mullins PA, Thuraisingham SI, et al. Effect of transcutaneous electrical nerve stimulation on coronary blood flow. Circulation. 1994;89:694-702.

84. Sanderson JE, Woo KS, Chung HK, et al. The effect of transcutaneous electrical nerve stimulation on coronary and systemic haemodynamics in syndrome X. Coron Artery Dis. 1996;7: 547-52.

85. de Vries J, Dejongste MJ, Durenkamp A, et al. The sustained benefits of long-term neurostimulation in patients with refractory chest pain and normal coronary arteries. Eur J Pain. 2007;11:360-5. https://DOI.org/10.1016/j.ejpain.2006.04.002.

86. Kronhaus KD, Lawson WE. Enhanced external counterpulsation is an effective treatment for syndrome X. Int J Cardiol. 2009;135:256-7. DOI: 10.1016/j.ijcard.2008.03.022.

87. Hambrecht R, Wolf A, Gielen S, et al. Effect of exercise on coronary endothelial function in patients with coronary artery disease. N Engl J Med. 2000;342:454-60. DOI:10.1056/NEJM200002173420702.

88. Asbury EA, Slattery C, Grant A, et al. Cardiac rehabilitation for the treatment of women with chest pain and normal coronary arteries. Menopause. 2008;15:454-60. DOI: $10.1097 / g m e .0 b 013 \mathrm{e} 31815982 \mathrm{eb}$.

89. Gokce N, Vita JA, McDonnell M, et al. Effect of medical and surgical weight loss on endothelial vasomotor function in obese patients. Am J Cardiol. 2005;95:266-8.

90. Raitakari OT, Adams MR, McCredie RJ, et al. Arterial endothelial dysfunction related to passive smoking is potentially reversible in healthy young adults. Ann Intern Med. 1999; 130:578-81.

91. O'Keefe JH, Gheewala NM, O'Keefe JO. Dietary strategies for improving post-prandial glucose, lipids, inflammation, and cardiovascular health. J Am Coll Cardiol. 2008;51:249-55. 
Sažetak

\title{
NEOPSTRUKTIVNA KORONARNA BOLEST - KLINIČKA VAŽNOST, DIJAGNOSTIKA, LIJEČENJE I PRIJEDLOG NOVE PATOFIZIOLOŠKE KLASIFIKACIJE
}

\begin{abstract}
Z. Makarović, S. Makarović, I. Bilić-Ćurčić, I. Mihaljević i D. Mlinarević
Novi podaci prikupljeni iz velikih kliničkih ispitivanja pokazuju da je neopstruktivna koronarna bolest (ne-OKB) klinički entitet koji se ne smije zanemariti. Procjenjuje se da se u 50\% ženske populacije koja se podvrgava koronarografiji dijagnosticira ne-OKB. Također postoji povećanje učestalosti ne-OKB u oba spola, što je vjerojatno posljedica postupnog širenja kliničkih indikacija za koronarografiju u bolesnika s anginom pektoris. Nadalje, s obzirom na povećani rizik od smrtnosti koji je nedavno ustanovljen, prognoza ne-OKB nije dobroćudna kao što se ranije mislilo. Međutim, koncept i definicija ne-OKB ostaju nedovoljno definirani, što uzrokuje poteškoće kako u dijagnozi tako i u liječenju. Jedan od glavnih nedostataka je dijagnostika ne-OKB koja se temelji na dijagnozi isključivanja. Nadalje, liječenje ne-OKB i dalje predstavlja velik izazov, a optimalnu terapiju tek treba odrediti. Postoje dvije glavne hipoteze koje objašnjavaju patofiziološke mehanizme ne-OKB. Ishemijska hipoteza temelji se na mikrovaskularnoj disfunkciji, a neishemijska hipoteza na promijenjenoj percepciji boli. Ovaj pregledni članak obuhvaća širok spektar patofizioloških mehanizama ne-OKB i predlaže novi način klasifikacije temeljen na glavnom poremećaju koji je uključen u patofiziologiju: tip I. (ishemijski mehanizam) i tip II. (ne-ishemijski mehanizam), ovisno o tome koji mehanizam prevladava. Nadamo se da će to omogućiti nove spoznaje u razumijevanju ovoga poremećaja, što dovodi do točne i rane dijagnoze i uspješnog liječenja, osobito s obzirom na povećani rizik smrtnosti kod ovih bolesnika.
\end{abstract}

Ključne riječi: Koronarne arterije, bolesti; Klasifikacija; Dijagnostika; Angiografja 